\title{
Fates of diatom carbon and trace elements by the grazing of a marine copepod
}

\author{
Yan $\mathrm{Xu}^{1,2}$, Wen-Xiong Wang ${ }^{1, *}$ \\ ${ }^{1}$ Department of Biology, The Hong Kong University of Science and Technology (HKUST), Clear Water Bay, Kowloon, \\ Hong Kong, SAR
}

${ }^{2}$ Present address: Department of Ecology and Evolutionary Biology, Princeton University, Princeton, New Jersey 08544, USA

\begin{abstract}
Radiotracer experiments were performed to quantify the carbon assimilation and efflux in a subtropical coastal copepod Acartia spinicauda, and the importance of copepod grazing on the release of $\mathrm{Cd}, \mathrm{Fe}$, Se and carbon, from diatoms of different sizes (4 to $100 \mu \mathrm{m}$ ) at different food con-

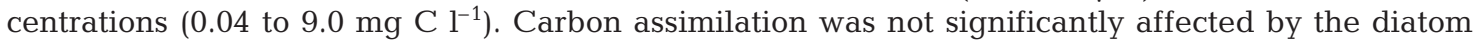
food concentration (Thalassiosira pseudonana, T. weissflogii and T. rotula) or the amount of food ingested, but was lower for the large diatom $T$. rotula than for the small diatom T. pseudonana. No significant relationship between carbon assimilation and gut passage time of food materials was observed. The efflux rate-constant (physiological turnover rate) of carbon ranged between 0.134 and $0.372 \mathrm{~d}^{-1}$ and was not significantly affected by diatom concentration ( $T$. weissflogii). During the physiological turnover period, over $50 \%$ of the copepod's carbon metabolic loss was in the form of dissolved organic carbon, whereas only a small fraction of carbon was lost in the form of feces. A significant fraction of the copepod's carbon was also lost through respiration, the relative importance of which decreased with increasing period of depuration. The retention of carbon, $\mathrm{Cd}, \mathrm{Fe}$, and Se by the diatoms (T. pseudonana, T. weissflogii, T. rotula, and Cosinodiscus sp.) was further compared in the presence and absence of the copepods. In general, there was no increase in the release of metals and carbon from the diatoms in the presence of grazing copepods regardless of diatom concentrations, suggesting that copepod grazing does not trigger significant releases of diatom metals and carbon directly into the ambient environment. Our results suggested that the excretion by zooplankton as well as leakage from fecal pellets presumably account for the majority of the zooplankton-mediated production and cycling of dissolved organic matter in the ocean.
\end{abstract}

KEY WORDS: Copepods · Assimilation · Efflux · Metals · Carbon · Dissolved organic carbon production

Resale or republication not permitted without written consent of the publisher

\section{INTRODUCTION}

Zooplankton is an important component of marine planktonic food webs, and thus plays a major role in organic carbon transport in the ocean. The ingested carbon is either assimilated by the copepods or lost (unassimilated) in the form of feces. Following assimilation, copepod carbon is either absorbed and incorporated into the tissues, or lost by excretion (in the form of dissolved organic carbon: DOC) and respiration (in the form of $\mathrm{CO}_{2}$ ). Although the influences of zooplank- ton grazing on the biogeochemical fate of carbon and metals have been studied rather extensively over the past 10 yr (Lee \& Fisher 1992a, Hutchins et al. 1993, Wang et al. 1996, Wang \& Fisher 1998a, Xu \& Wang 2001), the quantitative significance of different routes of carbon metabolic loss from copepods (e.g. excretion, egestion, respiration) is not exactly known.

Other processes during grazing, such as inefficient feeding, may contribute to the flux of carbon and metals from particulate to dissolved forms. Inefficient feeding of algal cells by zooplankton can lead to cell dam- 
age and thus the release of dissolved organic matter (DOM) from the cells into the surrounding water (Lampert 1978, Båmstedt et al. 2000). Preingestive (e.g. inefficient feeding) and postingestive processes (e.g. excretion and leakage from fecal pellets) are the major routes by which zooplankton contribute to DOM production (Eppley et al. 1981, Riemann et al. 1986, Hygum et al. 1997, Møller \& Nielsen 2001). Recent studies have indicated that 54 to $69 \%$ of the carbon ingested by copepods is released into the surrounding water when feeding on large phytoplankton diets (Møller \& Nielsen 2001), and that 5 to $15 \%$ of the metals in phytoplankton debris are released during zooplankton grazing (Lee \& Fisher 1994). Therefore, zooplankton-mediated DOM production is not only an important source for the microbial loop, but it also has a direct influence on the cycling of carbon and metals, as well as on the nutritional stoichiometry in the ocean.

To demonstrate the occurrence of DOC production, size-fractionated chl a analysis can be used to determine whether there is a build-up in the smallest size fraction due to the breakage of large diatoms into debris (Roy et al. 1989, Båmstedt et al. 2000). Direct experimental evidence also demonstrates the damage to phytoplankton cells under certain grazing situations (Conover 1966, Martin et al. 1970, Corner et al. 1972). The importance of DOM production can also be evaluated by comparing bacterial production with the presence of both phytoplankton and zooplankton or phytoplankton alone, or by directly measuring the production of DOM during zooplankton grazing (Lampert 1978, Williams \& Poulet 1986, Roman et al. 1988, Poulet et al. 1991, Peduzzi \& Herndl 1992, Kamjunke \& Zehrer 1999). However, direct evidence of inefficient feeding as a potential source for DOM production is not clearly established in these studies, because other biological processes, such as exudation by phytoplankton cells, excretion by zooplankton and release from egested fecal pellets, may all contribute to the total DOM production during relatively long incubation periods. To our knowledge, no study on DOM production has differentiated between the preingestive process (inefficient feeding) and the postdigestive process (excretion) by zooplankton. It is necessary to separate these processes before a quantitative analysis of the significance of inefficient feeding on total DOM production can be made.

In this study, we examined the assimilation and the physiological turnover of carbon by a coastal copepod Acartia spinicauda feeding on different diatom species of different sizes and at different concentrations. A. spinicauda is a dominant copepod species found in Hong Kong's coastal waters and the adjacent Pearl River Estuary regions. We further examined the influence of copepod grazing on the release of metals $(\mathrm{Cd}$,
$\mathrm{Fe}$, and $\mathrm{Se}$ ) and carbon by diatom cells by directly measuring metal and carbon retention by diatoms in the presence and absence of copepods. This method allows us to assess the controls on DOM production based on comparisons of element retention in diatoms. Previous studies generally indicated that inefficient feeding behavior may be more pronounced when the animals feed on large diatoms under conditions of excess food (Dagg 1974, Båmstedt et al. 2000). We thus considered a wide range of diatom size (4 to $100 \mu \mathrm{m}$ ). $\mathrm{Cd}, \mathrm{Fe}$, and Se were considered in this study largely because of their environmental and oceanographic relevance and their contrasting distributions in diatoms. Most $\mathrm{Fe}$ was associated with the non-cytoplasmic fraction (e.g. cell walls), whereas most Se and Cd were distributed in the cytoplasmic components (Reinfelder \& Fisher 1991, Hutchins et al. 1995, Wang \& Dei 2001, Wang et al. 2001). In our study, the amount of metals and carbon retained in the diatom cells during copepod grazing was monitored and compared with the control setting of the absence of copepods. The distribution of metals and carbon in cytoplasm of the diatoms was further determined to investigate the effect of grazing on DOM production. Because recycling of metals is possible and such recycling may lead to erroneous interpretations of the experimental results, controlled experiments were also concurrently conducted to quantify the potential recycling of metals by diatoms during their short-term exposure to copepods.

\section{MATERIALS AND METHODS}

Adult copepods, Acartia spinicauda, were collected by net towing $(250 \mu \mathrm{m}$ mesh size) from Port Shelter, Clear Water Bay, Hong Kong. The copepods were maintained under laboratory conditions for $1 \mathrm{~d}$, during which time they were fed diatoms prior to the experiments. All experiments were carried out in filtered seawater at $22^{\circ} \mathrm{C}$ and 30 psu salinity.

Radiolabeling the phytoplankton. Four species of diatoms, Thalassiosira pseudonana (CCPM 1335), T. weissflogii (CCMP 1048), T. rotula (CCMP 1647), and Coscinodiscus sp. (CCMP 1583), were obtained from the Provasoli-Guillard Phytoplankton Collection Center, Maine, USA, and were maintained in unialgal and clonal cultures in an $\mathrm{f} / 2$ medium at $18^{\circ} \mathrm{C}$ and under light illumination of $100 \mu \mathrm{mol}$ photons $\mathrm{m}^{-2} \mathrm{~s}^{-1}$, with a 14:10 h light:dark cycle. Cells in the late log phase were gently collected onto $3 \mu \mathrm{m}$ polycarbonate membranes (vacuum pressure of $\leq 5 \mathrm{~cm} \mathrm{Hg}$ ) or $60 \mu \mathrm{m}$ nylon mesh (for Coscinodiscus sp.) and were resuspended in $0.2 \mu \mathrm{m}$ of filtered seawater. The media for the tracemetal $(\mathrm{Cd}, \mathrm{Fe}$, and $\mathrm{Se})$ experiments were enriched with $\mathrm{f} / 2$ levels of $\mathrm{N}, \mathrm{P}, \mathrm{Si}$, and vitamins, and $\mathrm{f} / 20$ levels of 
trace metals without addition of $\mathrm{Cu}, \mathrm{Zn}$, and ethylenediaminetetraacetic acid (EDTA). The media for the carbon experiments were enriched with $f / 2$ medium. The initial cell concentration in the media was $1 \times 10^{5}$ cells $\mathrm{ml}^{-1}$ for $T$. pseudonana, $2 \times 10^{4} \mathrm{cells} \mathrm{ml}^{-1}$ for $T$. weissflogii, $3 \times 10^{4}$ cells ml ${ }^{-1}$ for $T$. rotula, and 50 cells ml $^{-1}$ for Coscinodiscus sp. The amounts of radioisotope additions for copepod grazing experiments were $111 \mathrm{kBq}$ of ${ }^{109} \mathrm{Cd}$ (in $0.1 \mathrm{~N} \mathrm{HCl}$ ), $148 \mathrm{kBq}$ of ${ }^{75} \mathrm{Se}(\mathrm{IV})$ (in $0.1 \mathrm{~N} \mathrm{HCl}$ ), and $222 \mathrm{kBq}$ of ${ }^{59} \mathrm{Fe}$ (in $0.1 \mathrm{~N} \mathrm{HCl}$ ); or $740 \mathrm{kBq}{ }^{14} \mathrm{C}\left(\mathrm{NaH}^{14} \mathrm{CO}_{3}\right.$, in distilled water). The amounts of radioisotope additions for carbon assimilation and efflux experiments were $111 \mathrm{kBq}$ of ${ }^{51} \mathrm{Cr}$ (III) (in $0.1 \mathrm{HCl}$ ) and $1110 \mathrm{kBq}{ }^{14} \mathrm{C}\left(\mathrm{NaH}^{14} \mathrm{CO}_{3}\right.$, in distilled water). The $\mathrm{pH}$ of the seawater was adjusted to 8.0 by the addition of $0.5 \mathrm{~N}$ Suprapur $\mathrm{NaOH}$. The carbon content of each algal diet was measured by a $\mathrm{CHN}$ Element Analyzer (Leco CHN-900) at $650^{\circ} \mathrm{C}$.

After 3 to $5 \mathrm{~d}$ growth, the cell density reached $1 \times$ $10^{6}$ cells $\mathrm{ml}^{-1}$ for Thalassiosira pseudonana, $2 \times$ $10^{5}$ cells ml ${ }^{-1}$ for $T$. weissflogii, $1 \times 10^{5} \mathrm{cells} \mathrm{ml}^{-1}$ for $T$. rotula, and 250 cells ml $^{-1}$ for Coscinodiscus sp., and they were considered to be uniformly radiolabeled. Cells were then collected by filtration onto $3 \mu \mathrm{m}$ polycarbonate membranes or onto $60 \mu \mathrm{m}$ nylon mesh (for Coscinodiscus sp.), rinsed with $0.1 \mathrm{mM}$ EDTA (in $0.2 \mu \mathrm{m}$ filtered seawater) to remove the weakly bound surface metals, and resuspended into $0.2 \mu \mathrm{m}$ of filtered unlabeled seawater. The cell density was counted before the cells were fed to the copepods.

Carbon assimilation by copepods at different diatom densities. Only Thalassiosira pseudonana, $T$. weissflogii and $T$. rotula were used in carbon assimilation experiments because there was no ingestion by copepods on large Coscinodiscus sp. Before the radioactive feeding, the copepods were placed in glass-fiber-filtered (GFF) seawater without the presence of food for $1 \mathrm{~h}$ to evacuate the copepod's guts. Copepods were then collected and added into the feeding beakers at a density of 0.7 ind. $\mathrm{ml}^{-1}$ and fed with the radiolabeled diatom cells at different densities for $30 \mathrm{~min}$ in the dark. There were 3 replicated beakers for each treatment. After the radioactive feeding, the copepods were collected with a $250 \mu \mathrm{m}$ nylon mesh, rinsed with filtered seawater, and were gammacounted for the radioactivity of ${ }^{51} \mathrm{Cr}(\mathrm{III})$. The copepods were immediately returned to $100 \mathrm{ml}$ GFF seawater to depurate for $12 \mathrm{~h}$ with the presence of unradiolabeled diatom cells at the same density as that used during the radioactive feeding. Any feces produced during the radioactive feeding were collected into the vials and counted for the radioactivity of ${ }^{51} \mathrm{Cr}(\mathrm{III})$ and later of ${ }^{14} \mathrm{C}$. Release of ${ }^{14} \mathrm{C}$ from egested feces into the ambient water was considered to be negligible during the short period $(<30 \mathrm{~min})$. The total amount of ${ }^{51} \mathrm{Cr}$ radioactivity ingested by copepods during the radioactive feeding (30 min) was the sum of radioactivity in the copepods determined immediately after the radioactive feeding and in the feces produced during this feeding period (some radioactive feces were produced during this period due to rapid gut passage of ingested diatoms). The fractions of ${ }^{51} \mathrm{Cr}(\mathrm{III})$ and ${ }^{14} \mathrm{C}$ in the radiolabeled diatom cells in the feeding suspension were also measured by filtering a $10 \mathrm{ml}$ aliquot onto a $1 \mu \mathrm{m}$ polycarbonate membrane. The radioactivity of ${ }^{51} \mathrm{Cr}(\mathrm{III})$ in copepods was measured every 1 to $4 \mathrm{~h}$ over the $12 \mathrm{~h}$ depuration period. The seawater and food were renewed after each radioactivity counting. Any feces produced during the depuration period were collected and counted for the radioactivity of ${ }^{51} \mathrm{Cr}$ (III) and ${ }^{14} \mathrm{C}$. After $12 \mathrm{~h}$ depuration, the copepods were collected and placed into the vials and counted for the radioactivity of ${ }^{51} \mathrm{Cr}$. The samples were added with cocktails and placed in the dark for at least $12 \mathrm{~h}$ before counting the radioactivity of ${ }^{14} \mathrm{C}$.

The cell densities used in the assimilation experiments were $0.036,0.16,0.64$ and $1.60 \mathrm{mg} \mathrm{Cl}^{-1}$ for Thalassiosira pseudonana, $0.038,0.15,0.60$ and $1.50 \mathrm{mg} \mathrm{C}$ $\mathrm{l}^{-1}$ for $T$. weissflogii, and $0.039,0.13,0.52$ and $1.31 \mathrm{mg}$ $\mathrm{C}^{-1}$ for $T$. rotula. The assimilation efficiency (AE) of carbon was calculated by the ${ }^{14} \mathrm{C}:{ }^{51} \mathrm{Cr}$-ratio method (Calow \& Fletcher 1972, Wang et al. 1996). Such method assumed a negligible assimilation of $\mathrm{Cr}$ by the copepods (see 'Results').

Carbon efflux (physiological turnover) by copepods at different diatom densities. Only Thalassiosira weissflogii was used in this experiment. The diatoms were radiolabeled with ${ }^{14} \mathrm{C}$ and fed to the copepods for measurements of carbon physiological turnover. The copepods were placed into 41 beakers and fed on the radiolabeled diatom cells at 7000 to 10000 cells ml$^{-1}$ for $1 \mathrm{~d}$. The radiolabeled diatoms were added to the feeding beakers every $6 \mathrm{~h}$ to maintain a relatively constant cell density. After the radioactive feeding, the copepods were collected, rinsed with filtered seawater and then placed into GFF seawater without the presence of food, to evacuate the guts, for $1 \mathrm{~h}$. The copepods were then transferred into $200 \mathrm{ml}$ beakers at 4 different diatom concentrations (each with 3 replicates), to depurate the assimilated carbon, for $2 \mathrm{~d}$. During the depuration period, 20 individual copepods and produced feces were collected every 3 to $8 \mathrm{~h}$, rinsed with filtered seawater and placed in the vial for radioactivity counting of ${ }^{14} \mathrm{C}$. A $10 \mathrm{ml}$ aliquot was also removed to measure the ${ }^{14} \mathrm{CO}_{2}$ respired by copepods and ${ }^{14} \mathrm{C}$ released by copepods' excretion using methods described in Lee \& Fisher (1992b) and Wang \& Guo (2001). Briefly, the water samples were acidified at $\mathrm{pH}$ $<2$ by addition of $70 \mu \mathrm{l} 6 \mathrm{~N} \mathrm{HCl}$, bubbled with $\mathrm{N}_{2}$ for 3 min to release ${ }^{14} \mathrm{CO}_{2}$, which was then absorbed in 
$3 \mathrm{ml} 1 \mathrm{M} \mathrm{NaOH}$. This fraction was considered as respired ${ }^{14} \mathrm{C}$. Any ${ }^{14} \mathrm{C}$ detected in the remaining water was considered as ${ }^{14} \mathrm{C}$ released by copepods' excretion (i.e. DOC). The seawater and food were renewed after the measurement of radioactivity in each compartment (respiration, excretion, copepods, feces). The cell densities during the depuration period were the same as the densities used in carbon assimilation experiment for T. weissflogii.

Ingestion rate and gut transit time of food particles (FPT) in copepods at different cell densities. The ingestion rates of copepods were quantified only for Thalassiosira weissflogii and T. rotula. The ingestion rate for T. pseudonana was not measured because of the low ingestion by the copepods on this diatom diet. Diatom cells were grown under the same conditions as used for assimilation experiments. Twenty individual copepods were placed in beakers containing $200 \mathrm{ml}$ of GFF seawater and diatom cells at the same densities as used in carbon assimilation experiments. Control treatments contained the same densities but without the presence of copepods. There were 3 replicates for each treatment. The copepods were fed on diatom cells in the dark for 3 to $5 \mathrm{~h}$. Any change in cell density during the feeding period was measured by a Coulter Counter. The ingestion rate was calculated by the equation described in Omori \& Ikeda (1992).

To determine the gut transit time of food particles, Thalassiosira pseudonana, T. weissflogii and T. rotula were separately fed to the copepods at different cell densities (the same as used in carbon assimilation experiments), to measure the time required for copepods to produce their first feces. The copepods were first placed in GFF seawater to evacuate their guts for $1 \mathrm{~h}$. Individual copepods were then placed in a deepwell dish containing $10 \mathrm{ml}$ of GFF seawater and diatom cells. Any feces produced were checked under a microscope every 1 to $3 \mathrm{~min}$. FPT was defined as the time required for the production of first feces by the copepods.

Influence of copepod grazing on the release of metals and carbon from diatom cells. Before the feeding experiments, the copepods were removed and allowed to evacuate their guts for $1 \mathrm{~h}$ in the absence of food particles. The radiolabeled algal cells were added to glass bottles containing $480 \mathrm{ml}$ of $0.2 \mu \mathrm{m}$ filtered seawater at different concentrations (Table 1), except for Coscinodiscus sp., which was added to plastic bot- tles containing $100 \mathrm{ml}$ of $0.2 \mu \mathrm{m}$ filtered seawater to avoid the diatom cells sticking to the surface of the bottles. The highest cell concentration (1 to $9 \mathrm{mg} \mathrm{C}^{-1}$, depending on different species of diatoms) was used to simulate algal concentration during the bloom period. Copepods reached their maximum ingestion rates at about 0.7 to $1.0 \mathrm{mg} \mathrm{C}^{-1}$ (see 'Results' and Liu \& Wang 2002). Copepods were added to 3 replicated bottles wrapped with aluminum foil for each treatment at densities of 40 to 80 ind. $\mathrm{l}^{-1}$ (20 to 40 ind. in $480 \mathrm{ml}$ filtered seawater) and were allowed to feed on the radiolabeled diatoms for $12 \mathrm{~h}$. A control treatment (with 3 replicates) containing the same concentrations of cells but without the copepods was used to monitor the release of radioisotopes by the diatom cells as well as the change in particle concentration during the incubation period. The feeding suspensions were kept homogeneous by rotating the bottles on a Ferris wheel at $5 \mathrm{rpm}$.

During the $12 \mathrm{~h}$ feeding period, a 10 to $20 \mathrm{ml}$ aliquot of cell suspension (for Thalassiosira pseudonana, $T$. weissflogii, and T. rotula) was first passed through a $60 \mu \mathrm{m}$ mesh to remove the copepods and the fecal pellets produced during feeding. It was then filtered onto a 1 (for T. pseudonana) or $3 \mu \mathrm{m}$ (for the other diatoms) polycarbonate membrane. The membranes were rinsed with filtered seawater, after which the radioactivity of the cells was measured. The cell suspension in the control treatment was also filtered using the same procedure. Any change in the cell density during the $12 \mathrm{~h}$ feeding period was monitored by a Coulter counter. For Coscinodiscus sp., a $2 \mathrm{ml}$ aliquot was visually separated from the copepods and then filtered onto a $3 \mu \mathrm{m}$ polycarbonate membrane for radioactivity 
measurement. Any change in the cell density was monitored by the cell count under a microscope.

The distribution of the radioisotopes in the diatom cytoplasm after copepod grazing was determined by differential centrifugation, as described in Reinfelder \& Fisher (1991). Briefly, the weakly bound surface metals were removed by $0.1 \mathrm{mM}$ EDTA. The cells were then suspended in distilled water and frozen. They were later thawed and centrifuged at $2000 \times g$ (15 min) and $20000 \times g(20 \mathrm{~min})$ sequentially. The supernatant after $20000 \times g$ centrifugation was defined as the cytoplasmic fraction.

Diatom uptake of released metals. Experiments were conducted to examine the influence of metal release by diatoms, fecal pellets and metal excretion by copepods on metal recycling. We examined the diatom uptake of desorbed metals from intact cells, of released metals from fecal pellets, and of excreted metals from the copepods. The diatom Thalassiosira weissflogii was radiolabeled as described above and resuspended into $0.2 \mu \mathrm{m}$ filtered seawater at different cell densities. Copepods were added to bottles wrapped with aluminum foil for each treatment at 40 to 80 ind. $\mathrm{l}^{-1}$ and were allowed to feed on the radiolabeled diatoms for $12 \mathrm{~h}$. A control treatment containing the same concentrations of the cells but without the copepods was used to monitor the release of radioisotopes by the diatom cells. The feeding suspensions were kept homogeneous by rotating the bottles on a Ferris wheel at $5 \mathrm{rpm}$. The cells, fecal pellets and copepods were removed by filtration onto the $0.2 \mu \mathrm{m}$ polycarbonate membrane. The filtrate $(150 \mathrm{ml}$ each, $\mathrm{n}=2)$ was then added into a polycarbonate bottle. The unradiolabeled diatom cells, which were grown under the same conditions as used in the radiolabeling, were added to the bottles at the same concentrations as those used in the feeding experiments. At $3 \mathrm{~h}$ time intervals a $10 \mathrm{ml}$ aliquot was filtered onto a $1 \mu \mathrm{m}$ polycarbonate membrane, rinsed with filtered seawater, and the radioactivity of the cells was counted. A $3 \mathrm{ml}$ aliquot was taken for measurement of the radioactivity in the water sample (including the diatoms). Any change in the cell density was monitored by a Coulter counter.

Radioactivity measurements. The radioactivity of gamma-emitting isotopes in the water and in algal particles was measured with a Wallac gamma detector. All measurements were related to appropriate standards and calibrated with spillover. The gamma emission of ${ }^{109} \mathrm{Cd}$ was determined at $88 \mathrm{keV}$, of ${ }^{51} \mathrm{Cr}$ (III) at $320 \mathrm{keV}$, of ${ }^{75} \mathrm{Se}$ at $264 \mathrm{keV}$, and of ${ }^{59} \mathrm{Fe}$ at $1092 \mathrm{keV} .{ }^{14} \mathrm{C}$ radioactivity was determined by a Beckman 6500 Scintillation Counter using the external standard ratio method. When the samples contained both ${ }^{14} \mathrm{C}$ and ${ }^{51} \mathrm{Cr}$, a standard curve was run to correct for spillover of ${ }^{51} \mathrm{Cr}$ on
${ }^{14} \mathrm{C}$ in beta counting (Wang \& Guo 2001). Counting times were adjusted to yield a propagated counting error of less than $5 \%$.

\section{RESULTS}

\section{Carbon assimilation efficiency at different diatom concentrations}

Very little ${ }^{51} \mathrm{Cr}$ was retained by the copepods Acartia spinicauda during the $12 \mathrm{~h}$ depuration period (Fig. 1). After $12 \mathrm{~h}$, the percentage of ${ }^{51} \mathrm{Cr}$ retained in the copepods was consistently less than $1.5 \%$ (except for Thalassiosira weissflogii at the lowest food concentration: $5.7 \%$ ), indicating that $\mathrm{Cr}$ was essentially inert to the copepods. The carbon AE was therefore calculated as

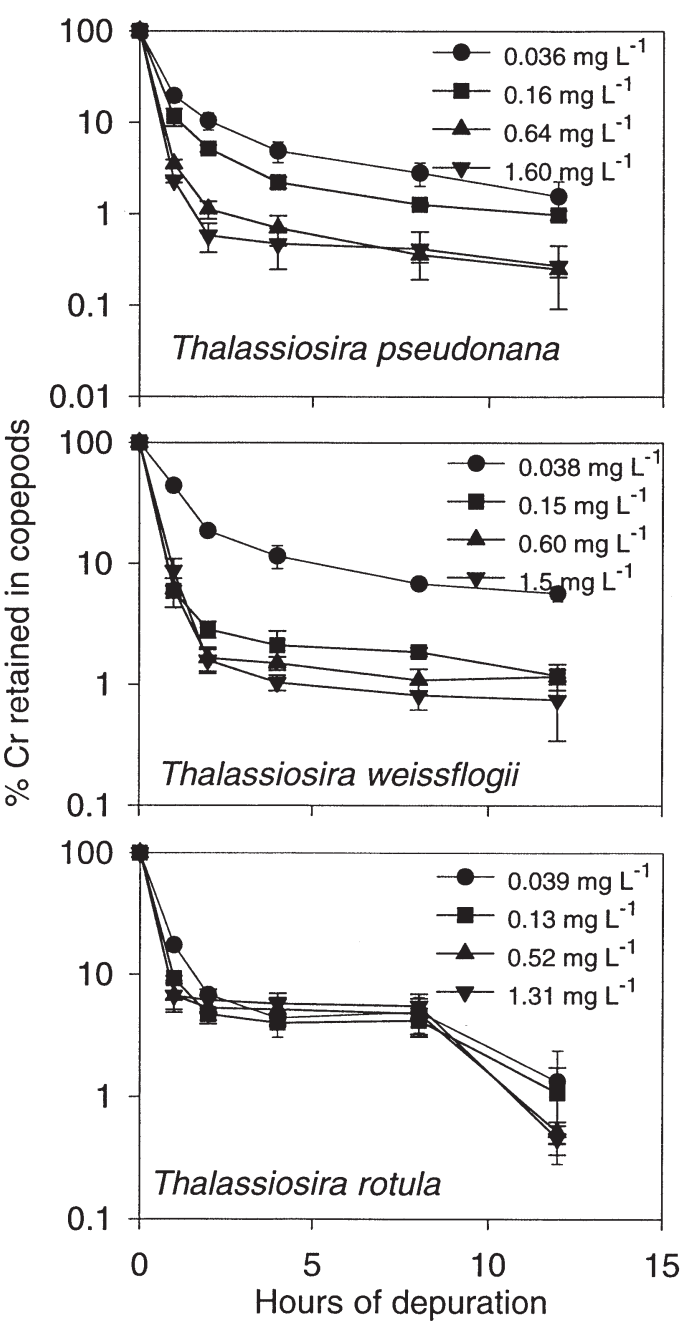

Fig. 1. Acartia spinicauda. Retention of ingested diatombound $\mathrm{Cr}$ by the copepods during the $12 \mathrm{~h}$ depuration period. Values are means $\pm \operatorname{SD}(\mathrm{n}=3)$ 
Table 2. Assimilation efficiency (AE) of carbon, ingestion rate (IR) and gut transit time of food particles (FPT) in the marine copepod Acartia spinicauda feeding on diatoms at different cell densities. Data are mean $\pm \mathrm{SD}(\mathrm{n}=3$ for $\mathrm{AE}$, IR, and 6 for FPT). ND: not determined

\begin{tabular}{|c|c|c|c|}
\hline $\begin{array}{l}\text { Cell biomass } \\
\left(\mathrm{mg} \mathrm{C}^{-1}\right)\end{array}$ & $\begin{array}{l}\mathrm{AE} \\
(\%)\end{array}$ & $\begin{array}{c}\text { IR } \\
\left(\mu \mathrm{g} \mathrm{C} \text { copepod }^{-1} \mathrm{~h}^{-1}\right)\end{array}$ & $\begin{array}{l}\text { FPT } \\
(\min )\end{array}$ \\
\hline \multicolumn{4}{|c|}{ Thalassiosira pseudonana } \\
\hline 0.036 & $90.7 \pm 0.3$ & ND & ND \\
\hline 0.16 & $95.3 \pm 0.5$ & ND & $77 \pm 11$ \\
\hline 0.64 & $92.3 \pm 0.5$ & ND & $31 \pm 6$ \\
\hline 1.60 & $92.3 \pm 0.7$ & ND & $28 \pm 7$ \\
\hline \multicolumn{4}{|c|}{ Thalassiosira weissflogii } \\
\hline 0.038 & $69.2 \pm 4.3$ & $0.051 \pm 0.004$ & $76 \pm 14$ \\
\hline 0.15 & $67.2 \pm 0.3$ & $0.140 \pm 0.020$ & $40 \pm 11$ \\
\hline 0.60 & $73.0 \pm 0.5$ & $0.180 \pm 0.010$ & $38 \pm 12$ \\
\hline 1.50 & $72.7 \pm 1.1$ & $0.210 \pm 0.050$ & $29 \pm 6$ \\
\hline \multicolumn{4}{|c|}{ Thalassiosira rotula } \\
\hline 0.039 & $51.8 \pm 6.8$ & $0.008 \pm 0.002$ & $65 \pm 8$ \\
\hline 0.13 & $53.4 \pm 7.9$ & $0.019 \pm 0.011$ & $31 \pm 9$ \\
\hline 0.52 & $50.8 \pm 3.2$ & $0.061 \pm 0.002$ & $25 \pm 5$ \\
\hline 1.31 & $58.8 \pm 9.2$ & $0.088 \pm 0.015$ & $18 \pm 3$ \\
\hline
\end{tabular}

the ratio method and is shown in Table 2. Food concentration did not significantly affect the $\mathrm{C}$ AE for all 3 diatom diets ( $p>0.05,1$-way ANOVA). The C AE was the highest for the diatom T. pseudonana (91 to $95 \%$ ), followed by $T$. weissflogii (67 to $73 \%$ ), and T. rotula (51 to $59 \%$ ). The quantified FTP of food materials ranged between 25 and $77 \mathrm{~min}$. We did not determine the FPT of T. pseudonana at the lowest food concentration because no feces was apparent at such a low food concentration. The FPT decreased with increasing diatom concentration in the water. When the interrelationships among $\mathrm{C} A E, F P T$, ingestion rate (IR), and diatom carbon concentration were considered, there was no relationship between the C AE and FPT, IR, or the diatom carbon concentration. A significant relationship was, however, found between the GPT or IR and the diatom carbon concentration (Fig. 2).

\section{Carbon physiological turnover at different diatom concentrations}

The retention of assimilated carbon by the copepods at different concentrations of diatom Thalassiosira pseudonana is shown in Fig. 3. After $2 \mathrm{~d}$ depuration, 54 to $69 \%$ of assimilated $\mathrm{C}$ was retained in the copepods, and the percentage of $C$ retention was not significantly affected by difference in diatom concentration. The physiological turnover rate constant (including excretion in the form of DOC, feces, and respired in the form of $\mathrm{CO}_{2}$ ) was calculated as the slope of the linear regression between the $\ln \%$ carbon retained in cope- pods and time of depuration (between 12 and $48 \mathrm{~h}$ ). The first 2 data points were ignored in the calculation of the physiological turnover rate because the early phase of depuration may potentially be involved with digestion and assimilation processes. Thus, the calculated physiological turnover rate constants were
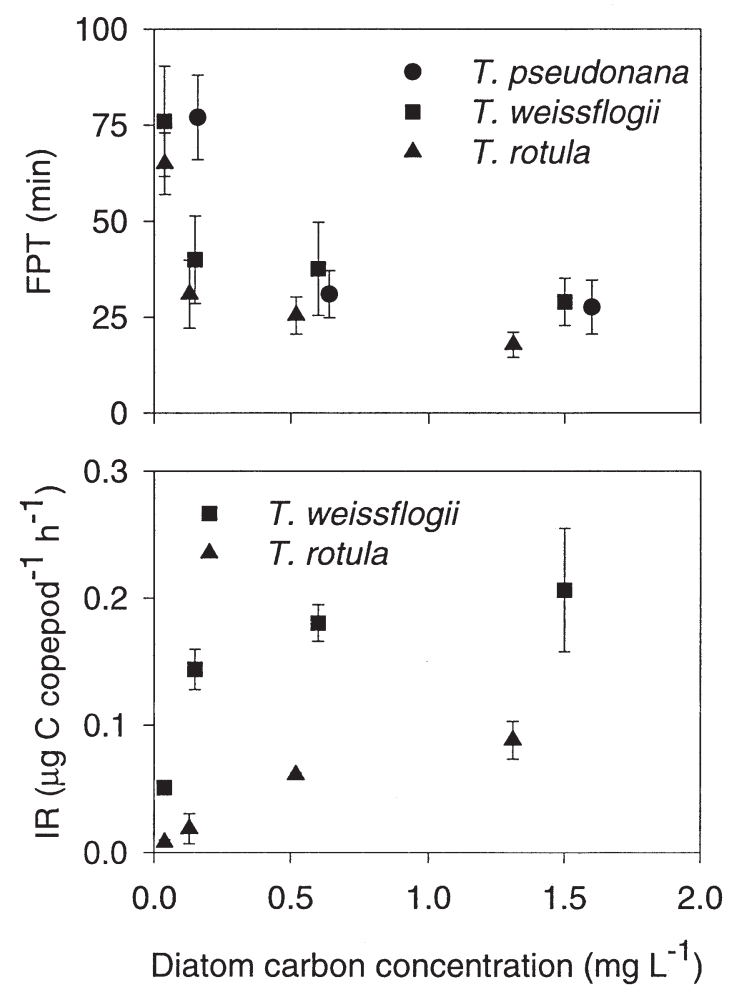

Fig. 2. Acartia spinicauda. Relationship between the gut passage time of food materials (FPT) (top panel) or ingestion rate (IR) of copepods, and the diatom carbon food concentration in the water. Values are means \pm SD ( $n=6$ for FPT and 3 for IR)

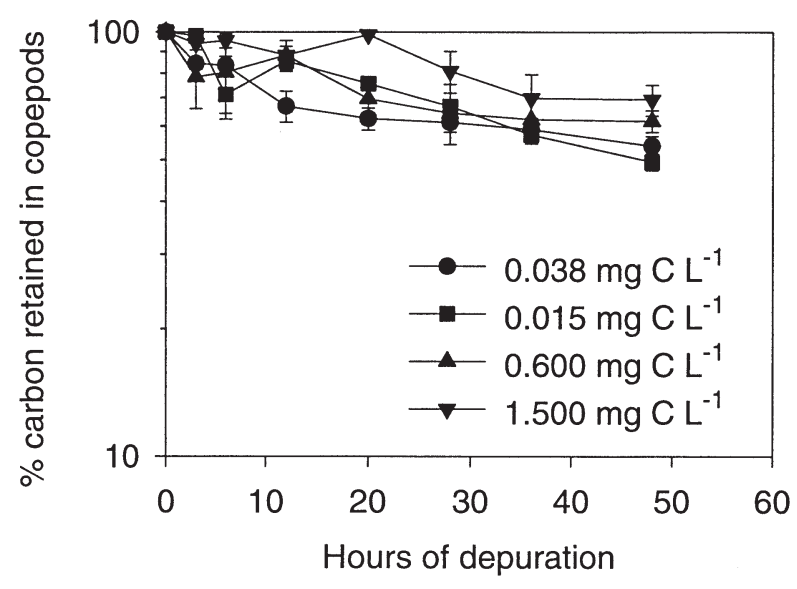

Fig. 3. Acartia spinicauda. Retention of assimilated carbon by the copepods during the $2 \mathrm{~d}$ depuration period. Values are means $\pm \operatorname{SD}(n=3)$ 
$0.133 \pm 0.049,0.372 \pm 0.060,0.214 \pm$ 0.086 , and $0.225 \pm 0.101 \mathrm{~d}^{-1}($ mean $\pm \mathrm{SD}$, $\mathrm{n}=3$ ) for $0.038,0.015,0.60$ and $1.5 \mathrm{mg} \mathrm{C}$ $\mathrm{l}^{-1}$, respectively.

The partitioning of copepods' carbon among 3 compartments (excretion in the form of DOC, feces, and respired in the form of $\mathrm{CO}_{2}$ ) during the $2 \mathrm{~d}$ depuration periods is shown in Fig. 4. The majority of the copepods' metabolic carbon was lost in the form of excreted DOC, and this ratio increased with increasing depuration period. For example, at $48 \mathrm{~h}$ of depuration, 68 to $75 \%$ of the copepods' metabolic carbon loss was in the form of excretion. Feces loss only contributed $<11 \%$ of total carbon loss from the copepods. Loss by respiration also contributed significantly to the overall metabolic loss from the copepods, but this ratio decreased with increasing depuration time. At 3 h, ca. 40 to $56 \%$ of carbon loss was by respiration, and by the end of depuration ( $48 \mathrm{~h}$ ), ca. 21 to $29 \%$ of carbon loss was by respiration. Food concentrations appeared to have little influence on the relative partitioning of the copepods' carbon in different compartments.

\section{Influence of copepod grazing on metal and carbon retention on diatom cells}

In general, the radioactivity of metals retained by the diatom cells decreased or was maintained relatively constant over time when the radiolabeled diatoms were resuspended in non-radioactive waters, and more $\mathrm{Cd}$ was released into the ambient seawater than Se and Fe in both the grazing and the control treatments (Figs. 5 to 7 ). For example, at the lowest concentration of Thalassiosira pseudonana, the amount of radioactivity of ${ }^{109} \mathrm{Cd}$ in the cells decreased by 75 to $80 \%$, whereas the radioactivity of ${ }^{75} \mathrm{Se}$ remained rather constant and the radioactivity of ${ }^{59} \mathrm{Fe}$ decreased by 24 to $36 \%$ after $12 \mathrm{~h}$ of resuspension. There was no notable decrease of the cellular Se and Fe between 3 and $12 \mathrm{~h}$ of resuspension except Coscinodiscus sp. The cellular metals were rather comparable among the different diatom concentration treatments.

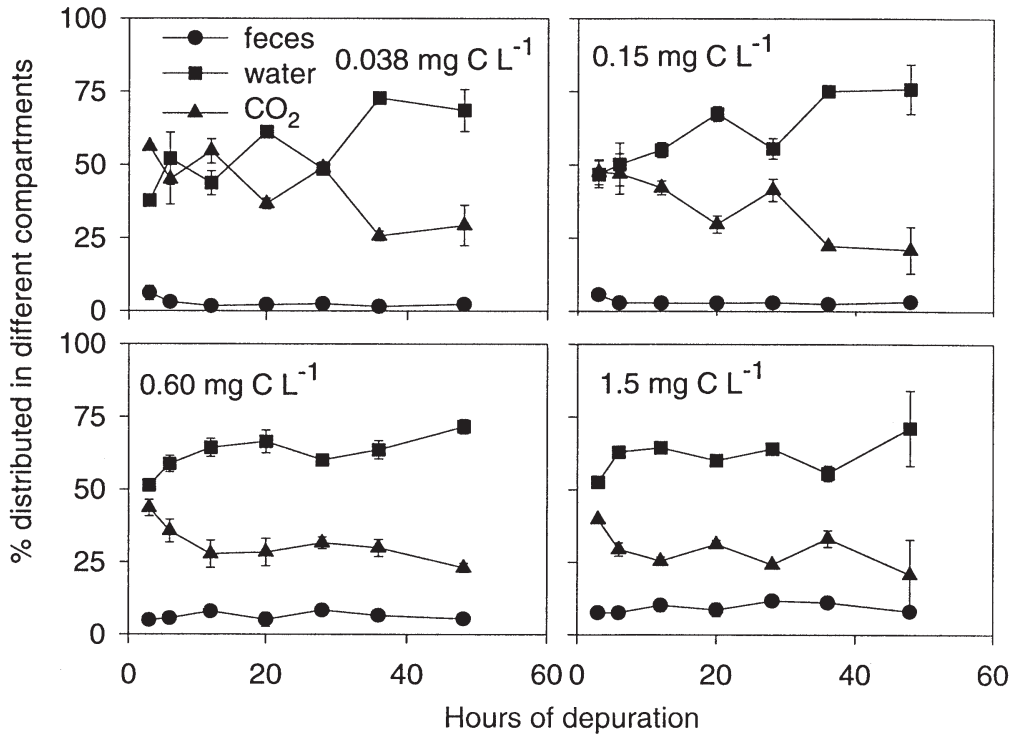

Fig. 4. Acartia spinicauda. Partitioning of metabolic carbon loss by copepods in different compartments (feces, excretion: water, and respiration: $\mathrm{CO}_{2}$ ) during the $2 \mathrm{~d}$ depuration period at different concentrations of diatom Thalassiosira weissflogii. Values are means \pm SD $(n=3)$

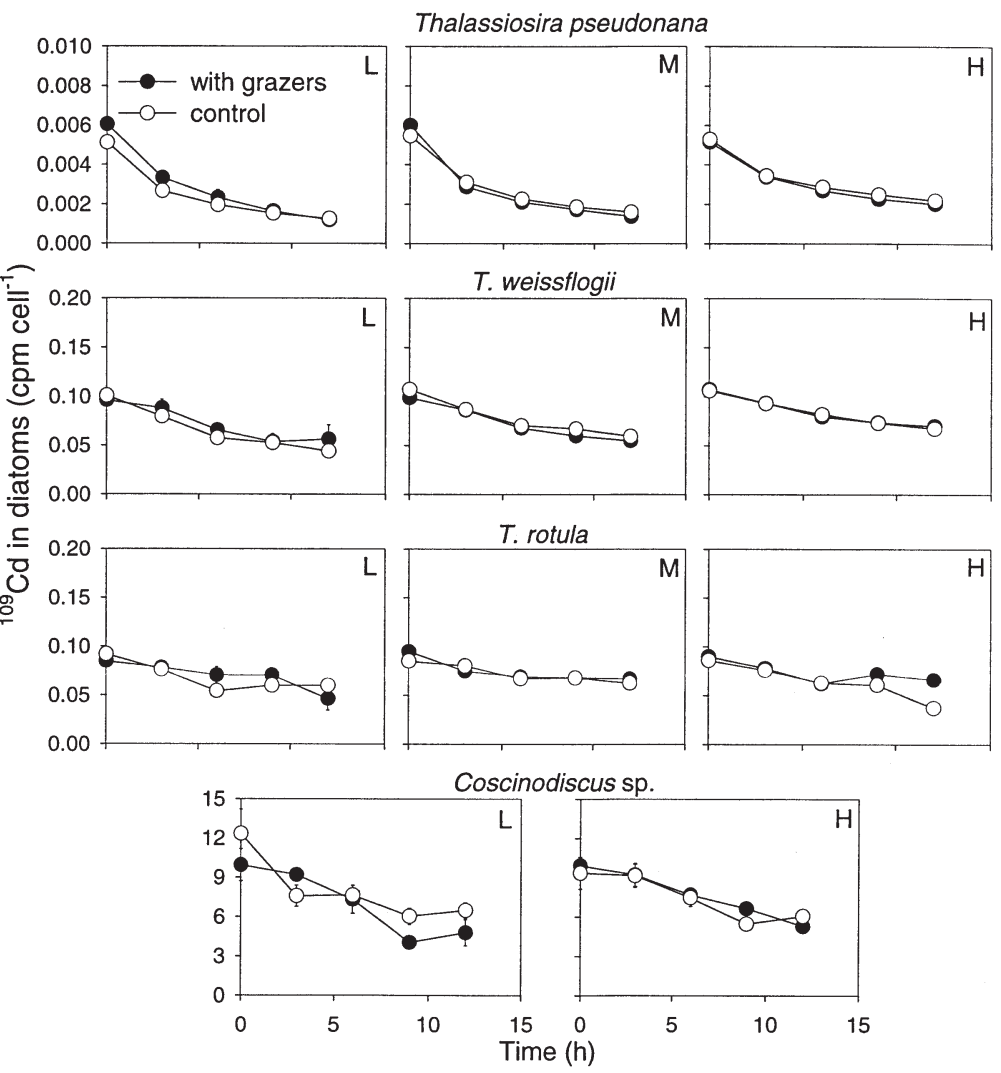

Fig. 5. Radioactivity of ${ }^{109} \mathrm{Cd}$ retained in the diatoms Thalassiosira pseudonana, T. weissflogii, T. rotula, and Coscinodiscus sp. incubated with and without the copepod Acartia spinicauda at different cell concentrations. L: low cell concentration; M: medium cell concentration; H: high cell concentration (see Table 1$)$. Values are means $\pm \mathrm{SD}(\mathrm{n}=3)$. In many cases, the $\mathrm{SD}$ is smaller than the symbol size indicated 


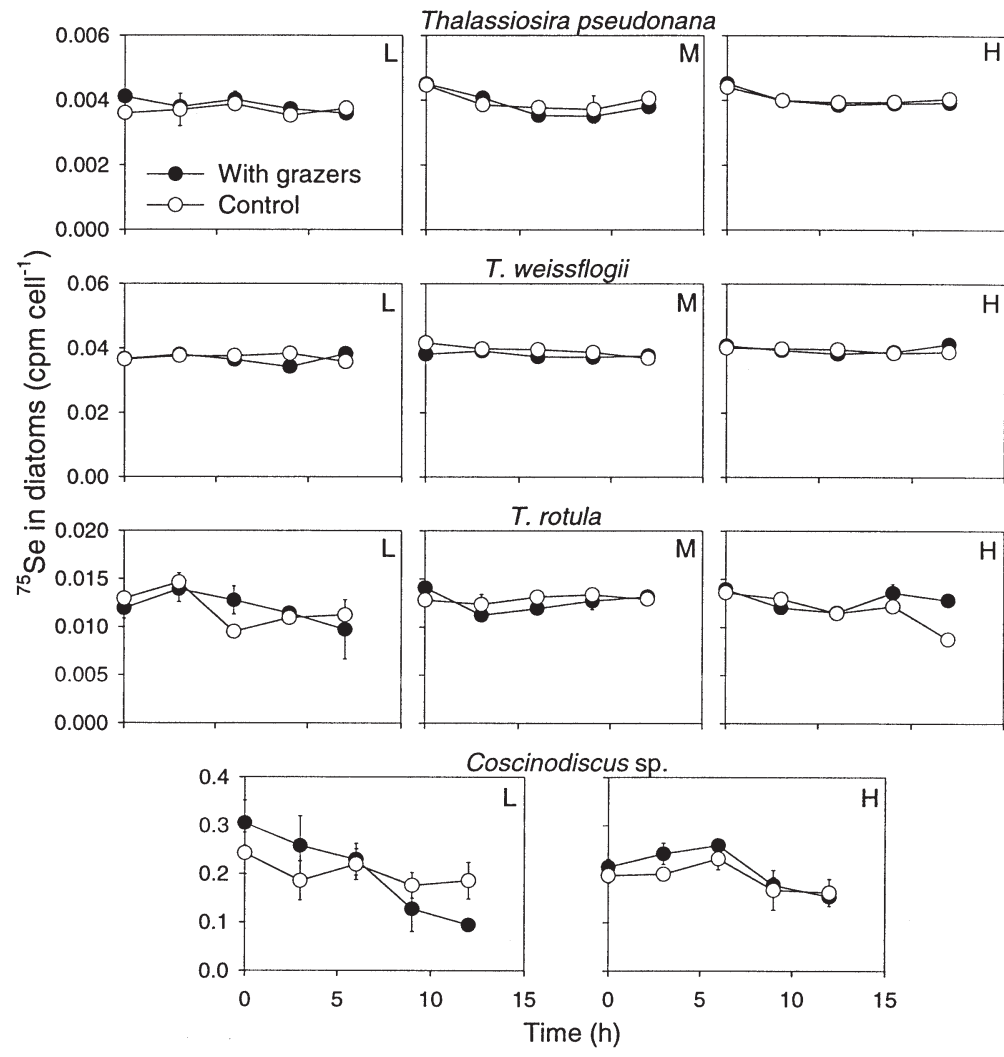

Fig. 6. Radioactivity of ${ }^{75} \mathrm{Se}$ retained in the diatoms Thalassiosira pseudonana, T. weissflogii, T. rotula, and Coscinodiscus sp. incubated with and without the copepod Acartia spinicauda at different cell concentrations. L: low cell concentration; M: medium cell concentration; $\mathrm{H}$ : high cell concentration (see Table 1). Values are means $\pm \mathrm{SD}(\mathrm{n}=3)$. In many cases, the $\mathrm{SD}$ is smaller than the symbol size indicated

There was no significant difference in the amount of metals retained by the diatoms between the grazing and the control treatments for all 4 diatom diets $(\mathrm{p}>$ $0.05, t$-test), with a few exceptions noted. For the large diatom Coscinodiscus sp., only 2 cell concentrations were employed in the experiment. Only in the lower food concentration after $9 \mathrm{~h}$ of exposure was the retention of metals $(\mathrm{Cd}, \mathrm{Se}$, and $\mathrm{Fe})$ by the diatoms consistently lower in the presence of grazers than in the control treatment. For example, at $12 \mathrm{~h}$ of exposure, the amounts of $\mathrm{Cd}, \mathrm{Se}$, and $\mathrm{Fe}$ retained in Coscinodiscus sp. with the presence of copepods were 4.5 to $12 \%$, 11 to $46 \%$, and 13 to $25 \%$ lower than the control treatment without copepod presence, but the difference was only significant for Se at $12 \mathrm{~h}$ of exposure $(\mathrm{p}<0.01$, $t$-test).

The retention of carbon from the radiolabeled diatoms during the $12 \mathrm{~h}$ exposure period was similar to the metal releases (Fig. 8). Carbon bound with Thalassiosira weissflogii and T. rotula remained constant during the $12 \mathrm{~h}$ exposure, whereas there was a decrease of carbon retention in $T$. pseudonana within the first $3 \mathrm{~h}$. The particle concentration did not affect the percentage of carbon retained by the diatoms. There was no significant difference in the amount of carbon retention between the grazing and the control treatments (except for $T$. rotula at low cell concentration), indicating that the grazing activity of the copepods did not greatly affect the carbon release from the diatoms, regardless of cell size and cell abundance.

The distribution of metals and carbon in the diatom cytoplasm for Thalassiosira rotula and Coscinodiscus sp. after $12 \mathrm{~h}$ of exposure in the presence or absence of grazers is shown in Fig. 9. In general, there was no significant difference $(\mathrm{p}>0.05, t$ test) in metal and carbon distribution in the diatom cytoplasm, with a few exceptions (e.g. Cd in T. rotula). Less Cd was distributed in the cytoplasm of $T$. rotula with increasing cell concentration.

\section{Diatom uptake of released metals}

During the $12 \mathrm{~h}$ exposure period, the metals may have been recycled between the diatoms and the water (e.g. desorption and resorption), the diatoms and the fecal pellets, and the diatoms and the copepods' excretion. We examined these possibilities by exposing unlabeled diatoms to metals released from radiolabeled intact cells, or from fecal pellets and copepod excretion. After $12 \mathrm{~h}$ of resuspension of radiolabeled diatoms in unlabeled seawater, about 63 to $80 \%$ of $\mathrm{Cd}$ had been released from the cells, whereas the amount of released Se and $\mathrm{Fe}$ was not sufficient for diatom uptake measurement. Overall, less than $2.5 \%$ of the released Cd was taken up by the diatom cells at all the cell concentrations (Fig. 10). The percentage of $\mathrm{Cd}$ accumulation by the diatoms was highest at lowest cell concentration, but there was no obvious increase in $\mathrm{Cd}$ accumulation with increasing exposure time. Consequently, although more than $60 \%$ of $\mathrm{Cd}$ was released from the radiolabeled diatoms into the dissolved phase after $12 \mathrm{~h}$ of resuspension, a negligible amount of the released $\mathrm{Cd}$ was possibly recycled by the diatoms. Moreover, there was no significant difference of metal uptake by diatoms between the presence of copepods and the control (without copepods), indicating that the recycling of released metals from fecal pellets and the excreted metals from copepods were negligible. 


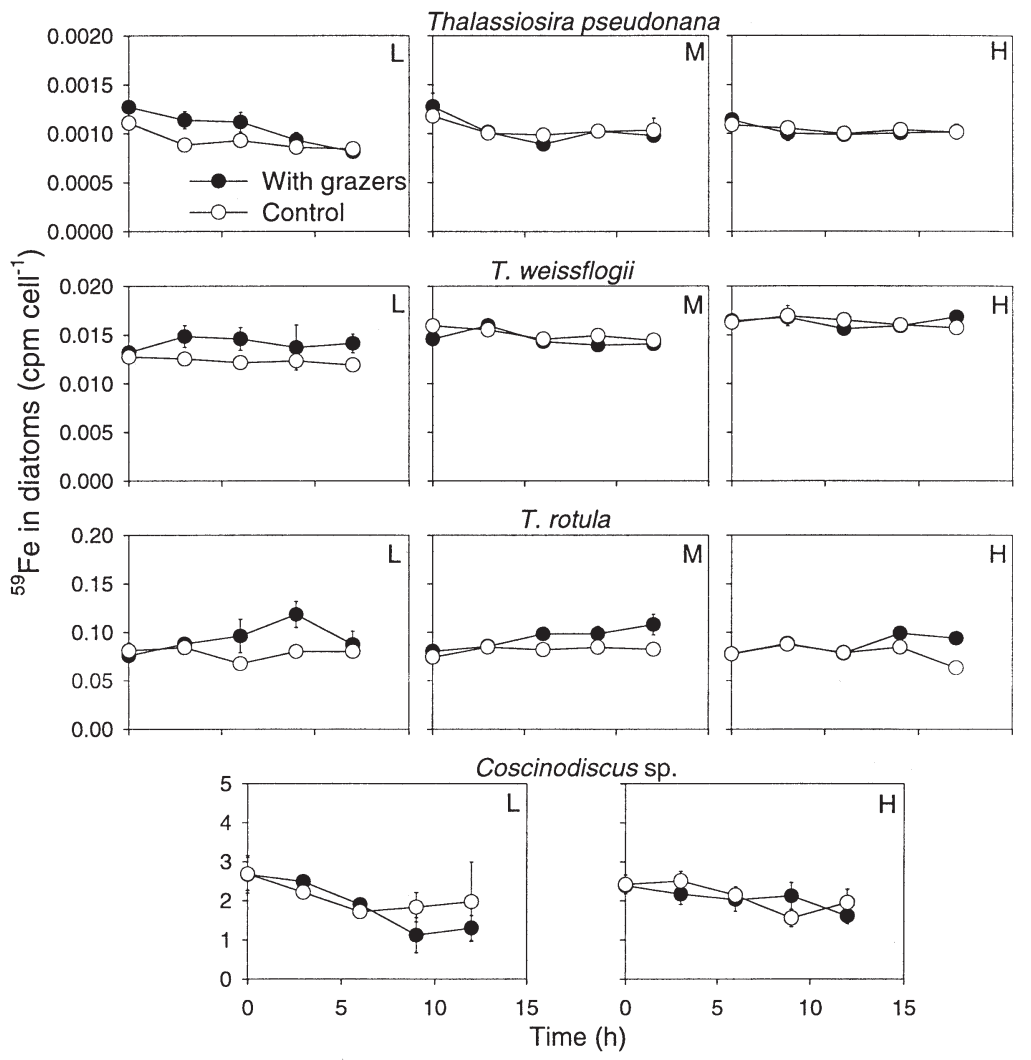

Fig. 7. Radioactivity of ${ }^{59} \mathrm{Fe}$ retained in the diatoms Thalassiosira pseudonana, $T$. weissflogii, $T$. rotula, and Coscinodiscus sp. incubated with and without the copepod Acartia spinicauda at different cell concentrations. L: low cell concentration; M: medium cell concentration; H: high cell concentration (see Table 1$)$. Values are means $\pm \mathrm{SD}(\mathrm{n}=3)$. In many cases, the $\mathrm{SD}$ is smaller than the symbol size indicated

tion by the copepod A. spinicauda was significantly dependent on the gut passage time of metals as well as on the food passage time (Xu \& Wang 2001).

The lager size of diatom was however less efficiently assimilated by the copepods. In our study, the C AE from Thalassiosira rotula was only 50 to $60 \%$, as compared to $>90 \%$ from smaller T. pseudonana. The lower AE may have been due to a higher fraction of carbon associated with the siliceous cellular wall, but this partitioning was not quantified in our study. Our study also found that the larger diatoms passed through the digestive tract of copepods at a faster rate than the passage of smaller diatoms such as T. pseudonana. No significant relationship between $\mathrm{C}$ assimilation and food passage time was, however, found when all 3 diatom diets were considered. Wang et al. (1996) found that the carbon AEs were 69 to $97 \%$ in copepods Acartia tonsa and T. longicornis feeding on algal diets of different sizes (diatoms, green algae, prasinophytes, dinoflagellates), but there was no consistent pattern that the $\mathrm{C}$ AE changed with food particle size. The ingestion rates of $A$. spinicauda quantified in this study were rather comparable to other Acartia species (reviewed in Mauchline 1998).

The physiological turnover rate measured in this study was in the range 0.13 to $0.37 \mathrm{~d}^{-1}$ for copepods at different food con-

\section{DISCUSSION}

\section{Carbon assimilation and efflux in the copepods}

Carbon AE by the subtropical copepod Acartia spinicauda was comparable to the C AE by other copepods measured by the ${ }^{14} \mathrm{C}:{ }^{51} \mathrm{Cr}$ method or other methods (Landry et al. 1984, Wang et al. 1996). For comparison, the C AEs in the temperate copepod A. tonsa and Temora longicornis feeding on the diatom Thalassiosira pseudonana were 93 to $97 \%$ (Wang et al. 1996). Several previous studies also demonstrated that there was no significant influence of phytoplankton concentration on the carbon assimilation by the copepods (Conover 1966, Abou Debs 1984, Wang et al. 1996), consistent with our present study. The difference in food passage time did not result in any significant difference in carbon assimilation at different food concentrations, suggesting that carbon assimilation is not a rate-limiting process in copepods, in contrast to metal assimilation. Recently, we showed that metal assimila- centrations. These values were somewhat comparable to the physiological turnover rate of metals in marine copepods (Wang \& Fisher 1998a,b, Xu et al. 2001). The physiological turnover-rate constants measured in a temperate copepod (Thalassiosira longicornis), for example, was 0.11 to $0.30,0.16$, and 0.08 to $0.11 \mathrm{~d}^{-1}$ for $\mathrm{Cd}, \mathrm{Se}$, and $\mathrm{Zn}$, respectively. In the same species of copepod, however, the carbon turnover rate was somewhat lower than the physiological turnover of metals, which was 0.55 to $0.60,0.67$ to 0.90 , and 0.58 to $0.62 \mathrm{~d}^{-1}$ for $\mathrm{Cd}$, Se, and Zn, respectively (Xu et al. 2001). There are very few data on the carbon physiological turnover (efflux) to compare with our data. Gerber \& Gerber (1978) reported that the daily metabolic carbon losses were $63 \%$ for Undinula vulgaris, and $88 \%$ for mixed small copepods. The \% of DOC released by the copepod Calanus pacificus was 17 to 19\% (Copping \& Lorenzen 1980) and 16 to $29 \%$ (Strom et al. 1997) of total carbon ingested. Zooplankton in the Sargasso Sea excreted 2 to $10 \%$ of body carbon on a daily basis in the form of DOC (Steinberg et al. 2000). 
Our study provides the first quantitative partitioning of carbon in marine copepods during the physiological turnover period. Excretion appears to be the dominant form of the loss of assimilated carbon from the copepods, as has been shown in a few previous studies (Hutchins et al. 1995, Wang et al. 1996, Xu \& Wang 2001). The relative partitioning of different routes was, however, not related to the food concentration, thus each process (e.g. excretion, digestion, respiration) may be equally affected by the metabolic activity as a result of change in diatom concentration. Our study, however, demonstrated that respiration represented a significant source for the metabolic loss of carbon by the copepods. Up to $56 \%$ of copepods' metabolic carbon loss may have been due to respiration, especially during the early phase of depuration. Since excretion represented a major route for carbon loss by the animals, further studies are required to examine the speciation of DOC excreted by zooplankton and its biological reactivity in the ocean.

\section{Regeneration of carbon and metals by copepod grazing}

Inefficient feeding may occur in many aquatic animals feeding on large prey cells (Dagg 1974) and at high food concentrations (Glibert 1998, Malone \& Ducklow 1990). In this study, we did not observe a significant effect of grazing by Acartia spinicauda on the retention of dissolved metals and carbon from different sizes of diatoms (4 to $100 \mu \mathrm{m}$ ) at different food concentrations $\left(0.04\right.$ to $\left.9.0 \mathrm{mg} \mathrm{C} \mathrm{C}^{-1}\right)$. For the largest size diatom (Coscinodiscus sp., 80 to $100 \mu \mathrm{m}$ ) used, there was a 4 to $46 \%$ decrease of metal retention in the diatoms in the presence of copepods at low food concentration, whereas there was no major difference in metal retention at high food concentrations. The retention of $\mathrm{C}$ in this large diatom was also not affected by copepod grazing. Our results are thus only partially in agreement with Møller \& Nielsen (2001), who found no detectable response of bacterial production to copepod A. tonsa grazing on small phytoplankton regardless of the cell concentration, but a positive correlation between the bacterial biomass and grazing on large phytoplankton. In that study, approximately 54 to $69 \%$ of the algal carbon was lost in the surrounding waters when $A$. tonsa fed the large diatom Ditylum brightwelli $(71 \times 32 \mu \mathrm{m})$ and dinoflagellate Ceratium lineatum $(110 \times 27 \mu \mathrm{m})$. Similarly, Strom et al. (1997) found insignificant fractions of ingested algal carbon released by Calanus pacificus grazing on small phytoplankton cells such as Thalassiosira weissflogii $(23 \times 16 \mu \mathrm{m})$ and Oxyrrhis marina $(23 \times 13 \mu \mathrm{m})$. They speculated that the copepods were able to ingest the entire algal cells without significant loss of carbon because of their small size of the cells. In addition, Corner et al. (1972) found no evidence of damage to the large diatom Biddulphia sinensis and no loss of soluble nitrogen and phosphorus from the grazing of $C$. helgolandicus.

Other studies have indicated that the loss of DOM can be a significant fraction resulting from zooplankton grazing in both freshwater and marine systems. For example, the loss was $17 \%$ for Daphnia pulex fed on 6 species of freshwater algae (Lampert 1978); $15 \%$ for the copepod Calanus hyperborus fed on Thalassiosira fluviatilis (Conover 1966); 9 to $21 \%$ for $C$. pacificus fed on T. fluviatilis, Coscinodiscus angstii, and natural phytoplankton

Fig. 8. Radioactivity of ${ }^{14} \mathrm{C}$ retained in the diatoms Thalassiosira pseudonana, T. weissflogii, T. rotula, and Coscinodiscus sp. incubated with and without the copepod Acartia spinicauda at different cell concentrations. L: low cell concentration; M: medium cell concentration; H: high cell concentration (see Table 1). Values are means $\pm \mathrm{SD}(\mathrm{n}=3)$. In many cases, the $\mathrm{SD}$ is smaller than the symbol size indicated 


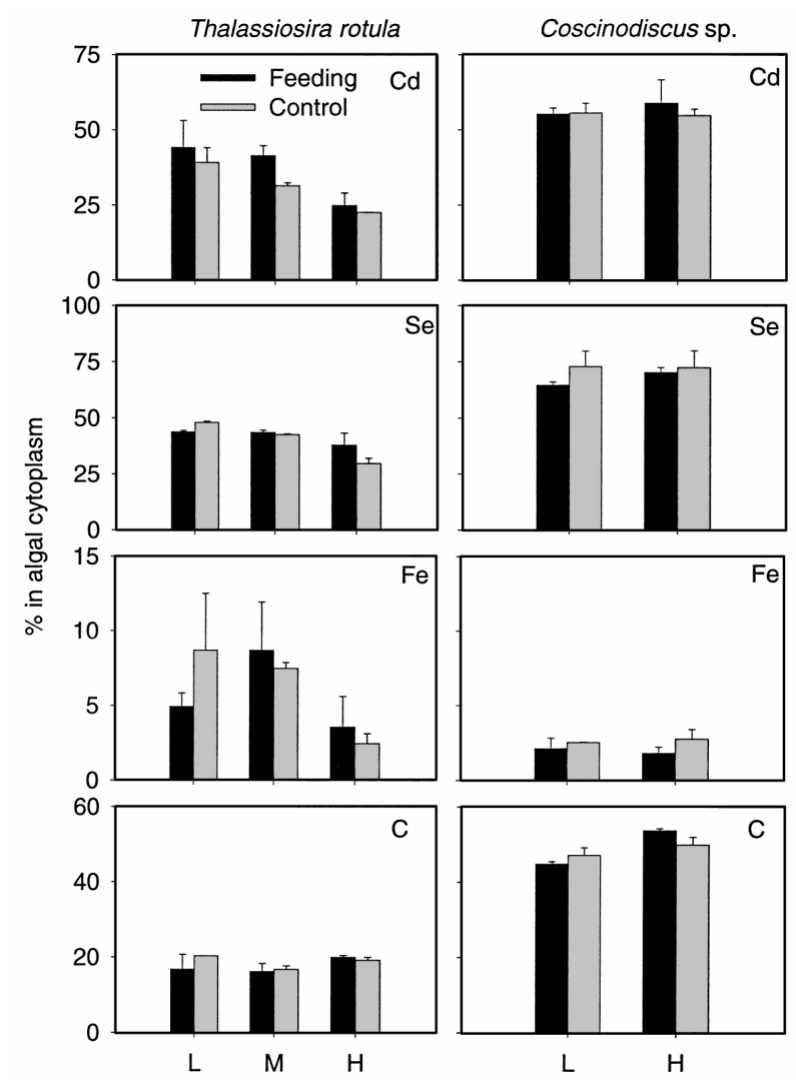

Fig. 9. Distribution of $\mathrm{Cd}, \mathrm{Se}, \mathrm{Fe}$, and $\mathrm{C}$ in the diatom cytoplasm after $12 \mathrm{~h}$ of incubation with (feeding) and without (control) the presence of the copepod Acartia spinicauda at different cell concentrations. L: low cell concentration; $\mathrm{M}$ : medium cell concentration; $\mathrm{H}$ : high cell concentration (see Table 1). Values are means \pm semi-range $(n=2)$

(Copping \& Lorenzen 1980); and $57 \%$ for cladocerans and copepods fed on Scenedesmus quandricauda and Rhodomonas lacustris (Hygum et al. 1997). Although Reimann et al. (1986) indicated that about 6 to $12 \%$ of DOM was released from the small cells $(<10 \mu \mathrm{m})$ during grazing by zooplankton, most of these previous studies suggested that DOM production occurred as a result of inefficient feeding when copepods fed on the large cells (Conover 1966, Lampert 1978, Strom et al. 1997, Møller \& Nielsen 2001). The behavioral and morphological phenotypes of the zooplankton may also be critical in determining the inefficiency in their feeding (Nagata 2000).

Lee \& Fisher (1994) demonstrated that copepod grazing had only a small effect on the release of $\mathrm{Ag}, \mathrm{Cd}$, $\mathrm{Co}, \mathrm{Pb}$ and $\mathrm{Po}$ (5 to $15 \%$ increase) from phytoplankton debris in the dissolved phase, and Wang \& Fisher (1998b) indicated that copepod grazing only slightly affected the fraction of $\mathrm{Cd}$ and Se but not $\mathrm{Ag}, \mathrm{Co}$, and $\mathrm{Zn}$ associated with diatom cells. Our results are generally consistent with the results of these 2 previ- ous studies, and suggest that inefficient feeding is unlikely to occur for different prey sizes and abundances, at least under the experimental conditions employed in our study.

It should be pointed out that most previous studies quantified only the production of DOM in the presence of zooplankton, but not the actual release of DOM due to inefficient feeding. During copepod grazing, several important processes may contribute to DOM production, including the direct release of metals and carbon from the phytoplankton cells (due to exudation or metal equilibrium), excretion by copepods as a metabolic by-product, leakage from fecal pellets produced during the feeding period, as well as inefficient feeding (Hygum et al. 1997, Nagata 2000, Møller \& Nielsen 2001). The relative contribution of each process to total DOM production was not clear in most of these previous studies. Long-term exposures (e.g. days) were generally employed in these previous studies, during which time the postdigestive processes (such as excre-

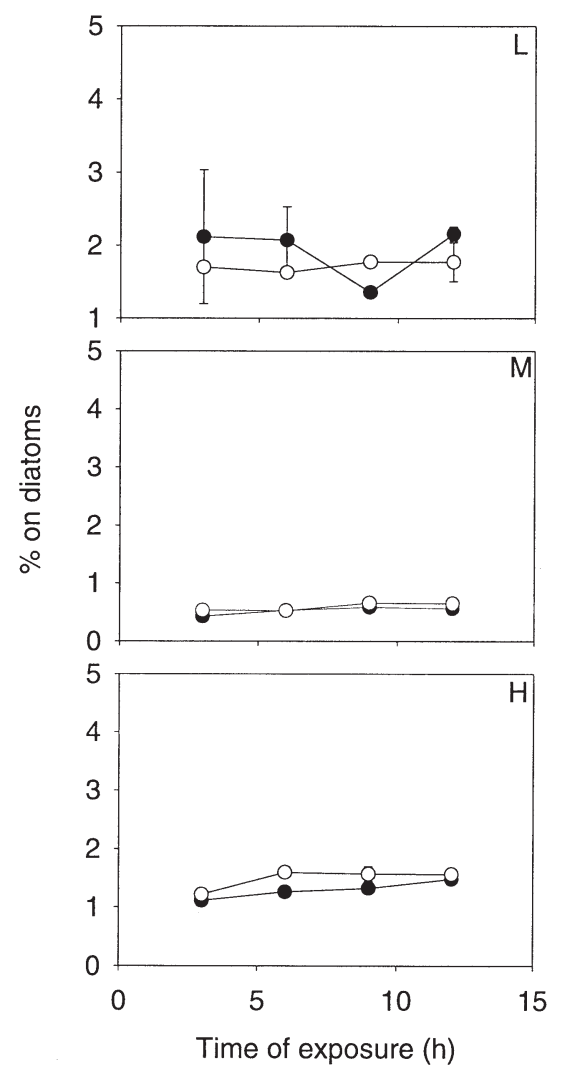

Fig. 10. Percentage of ${ }^{109} \mathrm{Cd}$ accumulated by the diatoms exposed to metals desorbed from the radiolabeled diatom Thalassiosira weissflogii (open circle) and released from fecal pellets and excreted by copepods (solid circle) at different cell concentrations. L: low cell concentration; M: medium cell concentration; H: high cell concentration (see Table 1). Values are means \pm semi-range $(n=2)$ 
tion) could contribute to the release of metals and carbon into the dissolved phase. Although it is relatively feasible to compare bacterial growth and DOM production in the presence and absence of grazers (Roman et al. 1988, Hygum et al. 1997, Kamjunke \& Zehrer 1999, Møller \& Nielsen 2001), separation of the relative contribution of pre- (inefficient feeding) and postdigestive processes, and release from fecal pellets requires more careful experimental designs. In our study, we quantified the metals or carbon retention on the diatoms in the presence and absence of copepods. The difference between these 2 treatments can be considered as the grazing contribution to the dissolved phase (including both excretion and inefficient feeding).

In our study, we observed that up to $70 \%$ of the radiolabeled $\mathrm{Cd}$ was released by the diatoms into the dissolved phase following suspension in the absence of copepods. Up to $25 \%$ of carbon was released into the ambient water within the first $3 \mathrm{~h}$ of suspension. Release of metals and carbon directly from the diatoms may reflect the repartitioning between the particulate and dissolved phases or exudation from the diatoms. Under natural conditions, the typical amount of extracellular release is about $13 \%$ of total carbon fixation. Much higher rates of release have been observed during the period of phytoplankton decomposition (Baines \& Pace 1991). Such release may potentially affect our interpretation of 'inefficient feeding' when no careful control treatments are used in the experiments (e.g. without adding the grazers).

Several potential problems may also affect the interpretation of our experimental results. The first is the potential recycling of metals between the diatoms and the water, between the diatom and the fecal pellets, or between the diatoms and the excreted metals. We quantified such potential recycling by measuring the accumulation of released metals by the intact cells. The results indicated that in general the recycling of all 3 metals was negligible. Among the 3 metals, Cd was most easily desorbed from the diatoms, and less than $2 \%$ of desorbed $\mathrm{Cd}$ may have been potentially recycled by the diatoms, suggesting that $\mathrm{Cd}$ was not readily taken up by the diatoms. The release of Se and Fe was less pronounced and the recycling of the desorbed metals by the diatoms was undetectable. Another potential problem was the accumulation by diatom cells of metals and carbon excreted by the copepods or leaked from fecal pellets during the grazing period. Previous studies have documented that marine copepods have an exceedingly high excretion rate of metals (Wang \& Fisher 1998a,b, Xu \& Wang 2001, Xu et al. 2001). To overcome this problem, we used a low density of copepods (40 to 80 ind. $\mathrm{l}^{-1}$ ) in the experiments. Furthermore, over the short-term $(12 \mathrm{~h})$ exposure period, the leakage of metals from fecal pellets was presumably small (Lee \& Fisher 1992a). Our control experiments also confirmed that the metals released from fecal pellets and excreted by copepods did not contribute to the recycling into diatoms during the $12 \mathrm{~h}$ exposure period.

Given that 'inefficient feeding' by copepods cannot account for all the production of DOM in the ocean, other processes of copepod grazing, including excretion and leakage from fecal pellets, may play important roles in grazer-mediated regeneration of metals over long periods. Excretion by zooplankton is an important pathway by which macronutrients such as $\mathrm{N}$ and $\mathrm{P}$ (Bulter et al. 1970, Landry 1993, Wen \& Peters 1994) and metals (Wang et al. 1996, Wang \& Fisher 1998b, $\mathrm{Xu}$ \& Wang 2001) are regenerated into the ambient environments as a result of the high physiological turnover rate in marine copepods. Egestion via fecal pellet production dominates the metal loss during the initial extracellular digestive period (Wang \& Fisher 1998b). Jumars et al. (1989) and Urban-Rich (1999) found that a significant fraction of carbon was diffused out of fecal pellets. The small size of the pellets and the sharp concentration gradient between pellet and ambient water are responsible for such loss (Jumars et al. 1989). Metal release from decomposing fecal pellets may also contribute to metal regeneration into the dissolved phase (Fisher et al. 1991, Lee \& Fisher 1992a, Wang et al. 1996, Wang \& Fisher 1998b).

In addition to zooplankton grazing, other biological processes, such as exudation by phytoplankton and cell lysis induced by viruses, can also contribute to the production of DOM (Peduzzi \& Herndl 1992, Gobler et al. 1997, Glibert 1998). Nagata (2000) integrated elementary mechanisms into a framework of DOM foodweb dynamics in the oceans. In his hypothetical model, grazers are the dominant source of DOM production in the ocean. About $65 \%$ of total DOM production can be accounted by grazer activity, $25 \%$ by phytoplankton, and $10 \%$ by viruses. Therefore, the interaction between zooplankton and phytoplankton rather than algal physiology alone dominates DOM production in the ocean. By regenerating DOM through excretion and leakage from fecal pellets, zooplankton thus play a pivotal role in the recycling of metals and carbon in the euphotic zone, and in the supply of nutrients and energy to the microbial loop. Postdigestive processes may predominantly contribute to the grazer-mediated regeneration of dissolved metals and organic carbon in the ocean.

Acknowledgements. We are grateful to the anonymous reviewers for their helpful comments on this work. This study was supported by Competitive Earmarked Research Grants from the Hong Kong Research Grants Council (HKUST6118/ 01M and N_HKUST603/01) to W.-X.W. 


\section{LITERATURE CITED}

Abou Debs C (1984) Carbon and nitrogen budget of the calanoid copepod Temora stylifera: effect of concentration and composition of food. Mar Ecol Prog Ser 15: 213-223

Baines SB, Pace ML (1991) The production of dissolved organic matter by phytoplankton and its importance to bacterial: patterns across marine and freshwater systems. Limnol Oceanogr 36:1078-1090

Båmstedt U, Gifford DJ, Irigoien X, Atkinson A, Roman M (2000) Feeding. In: Harris R, Wiebe P, Lenz J, Skjoldal HR, Huntley M (eds) ICES zooplankton methodology manual. Academic Press, New York, p 297-399

Calow P, Fletcher CR (1972) A new radiotracer technique involving ${ }^{14} \mathrm{C}$ and ${ }^{51} \mathrm{Cr}$ for estimating the assimilation efficiencies of aquatic, primary consumers. Oecologia 9: 155-170

Conover RJ (1966) Feeding on large particles by Calanus hyperboreus (Kroger). In: Barnes H (ed) Some contemporary studies in marine science. Allen \& Unwin, London, p 187-194

Copping AE, Lorenzen CJ (1980) Carbon budget of a marine phytoplankton-herbivore system with carbon-14 as a tracer. Limnol Oceanogr 25:873-882

Corner EDS, Head RN, Kilvington CC (1972) On the nutrition and metabolism of zooplankton. VIII. The grazing of Biddulphia cells by Calanus helgolandicus. J Mar Biol Assoc UK 52:847-861

Dagg MJ (1974) Loss of prey contents during feeding by an aquatic predator. Ecology 55:903-906

Eppley RW, Horrigan SG, Fuhrman JA, Brooks ER, Price CC, Sellner K (1981) Origins of dissolved organic matter in Southern California coastal waters: experiment on the role of zooplankton. Mar Ecol Prog Ser 6:149-159

Fisher NS, Nolan CV, Fowler SW (1991) Scavenging and retention of metals by zooplankton fecal pellets and marine snow. Deep-Sea Res 38:1261-1275

Gerber RP, Gerber MB (1979) Ingestion of natural particulate organic matter and subsequent assimilation, respiration and growth by tropical lagoon zooplankton. Mar Biol 52: $33-43$

Glibert PM (1998) Interactions of top-down and bottom-up control in planktonic nitrogen cycling. Hydrobiologia 363: $1-12$

Gobler CJ, Hutchins DA, Fisher NS, Cosper EM, SañudoWilhelmy S (1997) Release and bioavailability of C, N, P, $\mathrm{Se}$, and Fe following viral lysis of a marine chrysophyte. Limnol Oceanogr 42:1492-1504

Hutchins DA, DiTullio GR, Bruland KW (1993) Iron and regenerated production: evidence for biological iron recycling in 2 marine environments. Limnol Oceanogr 38: 1242-1255

Hutchins DA, Wang WX, Fisher NS (1995) Copepod grazing and the biogeochemical fate of diatom iron. Limnol Oceanogr 40:989-994

Hygum BH, Petersen JE, Søndergaard M (1997) Dissolved organic carbon released by zooplankton grazing activity-a high-quality substrate pool for bacteria. J Plankton Res 19:97-101

Jumars PA, Penry DL, Baross JA, Perry MJ, Frost BW (1989) Closing the microbial loop: dissolved carbon pathway to heterotrophic bacteria from incomplete ingestion, digestion and absorption in animals. Deep-Sea Res 36:483-495

Kamjunke N, Zehrer RF (1999) Direct and indirect effects of strong grazing by Daphnia galeata on bacterial production in an enclosure experiment. J Plankton Res 21:1175-1182
Lampert W (1978) Release of dissolved organic carbon by grazing zooplankton. Limnol Oceanogr 23:831-834

Landry MR (1993) Predicting excretion rates of microzooplankton from carbon metabolism and elemental ratios. Limnol Oceanogr 38:468-472

Landry MR, Hassett RP, Fagerness V, Downs J, Lorenzen CL (1984) Effect of food acclimation on assimilation efficiency of Calanus pacificus. Limnol Oceanogr 29:361-364

Lee BG, Fisher NS (1992a) Decomposition and release of elements from zooplankton debris. Mar Ecol Prog Ser 88: $117-128$

Lee BG, Fisher NS (1992b) Degradation and elemental release rates from phytoplankton debris and their geochemical implications. Limnol Oceanogr 37:1345-1360

Lee BG, Fisher NS (1994) Effects of sinking and zooplankton grazing on the release of elements from planktonic detritus. Mar Ecol Prog Ser 110:271-281

Liu S, Wang WX (2002) Feeding and reproductive responses of marine copepods in South China Sea to toxic and nontoxic phytoplankton. Mar Biol 140:595-603

Malone TC, Ducklow HW (1990) Microbial biomass in the coastal plume of Chesapeake Bay: phytoplanktonbacterioplankton relationships. Limnol Oceanogr 35: $296-312$

Martin JH (1970) Phytoplankton-zooplankton relationships in Narragansett Bay. 4. The seasonal importance of grazing. Limnol Oceanogr 15:413-418

Mauchline J (1998) The biology of calanoid copepods. Adv Mar Biol 33:1-710

Møller EF, Nielsen TG (2001) Production of bacterial substrate by marine copepods: effect of phytoplankton biomass and cell size. J Plankton Res 23:527-536

Nagata T (2000) Production mechanisms of dissolved organic matter. In: Kirchman DL (ed) Microbial ecology of the oceans. John Wiley, New York, p 121-152

Omori M, Ikeda I (1992) Methods in marine zooplankton ecology. Krieger, Malabar, FL

Peduzzi P, Herndl GJ (1992) Zooplankton activity fueling the microbial loop: differential growth response of bacterial form oligotrophic and eutrophic waters. Limnol Oceanogr 37:1087-1092

Poulet SA, Williams R, Conway DVP, Videau C (1991) Cooccurrence of copepod and dissolved free amino acids in shelf sea waters. Mar Biol 108:372-485

Reinfelder JR, Fisher NS (1991) The assimilation of elements ingested by marine copepods. Science 251:794-796

Riemann B, Jørgensen NOG, Lampert W, Fuhrman JA (1986) Zooplankton induced changes in dissolved free amino acids and in production rates of freshwater bacteria. Microb Ecol 12:247-258

Roman RM, Ducklow HW, Fuhrman JA, Garside C, Glibert PM, Malone TC, McManus GB (1988) Production, consumption and nutrient cycling in a laboratory mesocosm. Mar Ecol Prog Ser 42:39-52

Roy S, Harris RP, Poulet SA (1989) Inefficient feeding by Calanus helgoandicus and Temora longicornis on Coscinodiscus wailesii: quantitative estimation using chlorophylltype pigments and effects on dissolved free amino acids. Mar Ecol Prog Ser 52:145-153

Steinberg DK, Carlson CA, Bates NR, Goldthwait SA, Madin LP, Michaels AF (2000) Zooplankton vertical migration and the active transport of dissolved organic and inorganic carbon in the Sargasso Sea. Deep Sea-Res I47: $287-300$

Strom SL, Benner R, Ziegler S, Dagg MJ (1997) Planktonic grazers are a potentially important source of marine dissolved organic carbon. Limnol Oceanogr 42:1364-1374 
Urban-Rich J (1999) Release of dissolved organic carbon from copepod fecal pellets in the Greenland Sea. J Exp Mar Biol Ecol 232:107-124

Wang WX, Dei RCH (2001) Biological uptake and assimilation of iron by marine plankton: influences of macronutrients. Mar Chem 74:213-226

Wang WX, Fisher NS (1998a) Accumulation of trace elements in a marine copepod. Limnol Oceanogr 43:273-283

Wang WX, Fisher NS (1998b) Excretion of trace elements by marine copepods and their bioavailability to diatoms. J Mar Res 56:713-729

Wang WX, Guo L (2001) Production of colloidal carbon and trace metals by phytoplankton decomposition. Limnol Oceanogr 46:278-286

Wang WX, Reinfelder JR, Lee BG, Fisher NS (1996) Assimilation and regeneration of trace elements by marine copepods. Limnol Oceanogr 41:70-81

Editorial responsibility: Otto Kinne (Editor),

Oldendorf/Luhe, Germany
Wang WX, Dei RCH, Xu Y (2001) Cadmium uptake and trophic transfer in coastal plankton under contrasting nitrogen regimes. Mar Ecol Prog Ser 211:293-298

Wen YH, Peters RH (1994) Empirical models of phosphorus and nitrogen excretion rates by zooplankton. Limnol Oceanogr 39:1669-1679

Willams R, Poulet SA (1986) Relationship between the zooplankton, phytoplankton, particulate matter and dissolved free amino acids in the Celtic Sea. Mar Biol 90:279-284

Xu Y, Wang WX (2001) Individual responses of trace element assimilation and physiological turnover by marine copepod Calanus sinicus to changes in food quantity. Mar Ecol Prog Ser 218:227-238

Xu Y, Wang WX, Hsieh DPH (2001) Influences of metal concentration in phytoplankton and seawater on metal assimilation and elimination in marine copepods. Environ Toxicol Chem 20:1067-1077

Submitted: October 23, 2002; Accepted: March 11, 2003

Proofs received from author(s): May 14, 2003 